DOI 10.22363/2618-897X-2021-18-1-20-28

Research Article

\title{
Russian Language in Kazakhstan: Specific Learning and Functioning in the Context of Interlingual Interaction
}

\author{
Ye.A. Zhuravleva ${ }^{1}$, A.E. Agmanova ${ }^{2}$ \\ ${ }^{1}$ L.N. Gumilyov Eurasian National University \\ 2, Satpayev Str., Nur-Sultan, 010008, Republic of Kazakhstan \\ 2 Pavlodar Pedagogical University \\ 60, Mira Str., Pavlodar, 140003, Republic of Kazakhstan
}

\begin{abstract}
The diversity and specificity of cultures and languages of ethnic groups, living on the territory of Kazakhstan, create a special socio-cultural context of the Eurasian space, demonstrating the model of modern interethnic linguistic and socio-cultural interaction. Uniqueness of social and communicative space of the country, characterized by the dominance of the state Kazakh and Russian languages - languages of two large ethnic groups - against a background of great linguistic diversity, determines the significance of the study of their interaction and mutual influence in the context of a multicultural society. This paper analyzes the issues of language interaction in polyethnic state, forms and methods of foreign language influence on Russian language. The issues of learning and functioning of the Russian language are considered as a native and as a second languauge. Active processes due to features of the interaction of the Kazakh and Russian languages are analyzed as 1) speech activity of ethnic Russians; 2) Russian speech of other ethnic groups; 3) learning and using Russian language by repatriates-Kazakhs and foreign citizens.
\end{abstract}

Key words: multicultural environment; language contacts, interaction of languages; intercultural competence

\section{Article history:}

Received: 03.10.2020

Accepted: 14.12.2020

Moderator: U.M. Bakhtikireeva

\section{Conflict of interests: none}

\section{For citation:}

Zhuravleva, Ye.A., and A.E. Agmanova. 2021. "Russian Language in Kazakhstan: Specific Learning and Functioning in the Context of Interlingual Interaction". Polylinguality and Transcultural Practices, 18 (1), 20-28. DOI 10.22363/2618-897X-2021-18-1-20-28

(C) Zhuravleva Ye.A., Agmanova A.E., 2021

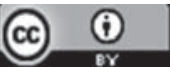

This work is licensed under a Creative Commons Attribution 4.0 International License https://creativecommons.org/licenses/by/4.0/ 


\title{
Русский язык в Казахстане: особенности обучения и Функционирования в контексте межъязыкового взаимодействия
}

\author{
Е.А. Журавлёва ${ }^{1}$, А.Е. Агманова ${ }^{2}$ \\ ${ }^{1}$ Евразийский национальный университет имени Л.Н. Гумилёва \\ Республика Казахстан, 010008, Нур-Султан, ул. Сатпаева, 2 \\ ${ }^{2}$ Павлодарский педагогический университет \\ Республика Казахстан, 140003, Павлодар, ул. Мира, 60
}

\begin{abstract}
Аннотация. Многообразие и специфика культур и языков этносов, проживающих на территории Казахстана, создают особый социокультурный контекст евразийского пространства, демонстрируя модель современного межэтнического языкового и социокультурного взаимодействия. Своеобразие социально-коммуникативного пространства страны, характеризующееся доминированием государственного казахского и русского языков - языков двух крупных этнических групп - на фоне большого языкового разнообразия, определяет значимость изучения их взаимодействия и взаимовлияния в контексте мультикультурного общества. В статье анализируются вопросы языкового взаимодействия в полиэтническом государстве, формы и методы воздействия иностранного языка на русский язык. Рассмотрены вопросы изучения и функционирования русского языка как родного и как второго. Активные процессы, обусловленные особенностями взаимодействия казахского и русского языков, анализируются как речевая деятельность этнических русских; русская речь других этносов; изучение и использование русского языка репатриантами-казахами и иностранными гражданами.
\end{abstract}

Ключевые слова: мультикультурная среда, языковые контакты, взаимодействие языков, межкультурная компетентность

\section{История статьи:}

Дата поступления в редакцию: 03.10.2020

Дата принятия к печати: 14.12.2020

Модератор: У.М. Бахтикиреева

Конфликт интересов: отсутствует

\section{Для цитирования:}

Журавлёва Е.А., Агманова А.Е. Русский язык в Казахстане: особенности обучения и общения в контексте межъязыкового взаимодействия // Полилингвиальность и транскультурные практики. 2020. Т. 18. № 1. С. 20-28. DOI 10.22363/2618-897X-2021-18-1-20-28

\section{Introduction}

It is well-known that the promotion of a peaceful dialogue between various national cultures, particularly in the context of a direct contact of several languages within the boundaries of a state or even a group of multinational states, remains to be the vital concern of these states which seek to maintain and develop civilized forms of interaction 
and cooperation among different peoples who, as it is often the case, share long-standing traditions of coexistence in spiritual, social, and economic spheres. The solution to the issue of the individual's development who finds himself at the intersection of various cultures and languages lies, in our view, in the solution of a whole set of socio-psychological, pedagogical, linguistic and methodological problems. Approaches to each of the above mentioned problems and their solution are closely connected to the socio-cultural aspect of research which we examine in this paper.

The Republic of Kazakhstan is currently going through a new phase of its development which is characterized by the intensification of the interaction process at both intercultural and interpersonal levels, not to mention the impact of globalization on all spheres of social life. The population of Kazakhstan consists of more than 130 ethnic groups, thus, creating excellent conditions for a unique language situation and great opportunities for researchers to look into various intercultural communication and language contact problems arising from multi-ethnic and language diversity. Although there are many different ethnic groups, the overwhelming majority is represented by the speakers of the official Kazakh and Russian languages. Therefore, it is, for the most part, the close interaction of these two languages in different social contexts that makes the language situation so specific in the country.

The phenomenon of massive Kazakh-Russian bilingualism emerged as a result of a series of historical and political events, and, above all, as a result of an extensive 'russification' policy. Following the 'russification' policy, during a long time, numerous ethnic groups interacted with each other in socioeconomic, public and cultural spheres primarily in Russian. As western scholars Dave and Sinnott have observed, the so called "Russified cultural landscape" was once heavily predominant in Kazakhstan [1]. The change in the language situation in favour of the official Kazakh language, whose position has steadily been reinforced during the years of independence, is taking place in the context of massive bilingualism in which Russian still plays a considerable role.

Taking into account the role of Russian in the modern world, questions of mastering Russian as a second language in a multi-ethnic country, in our view, are of particular interest. It should be noted that in Kazakhstan Russian is studied as 1) a first (native), 2) second, and 3) foreign language.

In regard to all that has been mentioned above, the following main aspects of Russian, functioning as a first and second language, and active processes determined by the specific features of interaction between Kazakh and Russian, are analysed: 1) speech of the ethnic Russians; 2) speech of the speakers of Russian for whom Russian is a second language; 3 ) the learning and use of Russian by Kazakh repatriates and foreign citizens.

\section{The influence of language contacts on the development of the Kazakhstan variant of the Russian language}

Languages with several centres of development in which national variants are constantly developing with their own linguistic processes, own norms and a certain official status, are normally called multi-national in linguistics. Their characteristic feature is "national variability" which is a kind of manifestation of a certain language system in the respective national centre. English, Spanish, French, etc. can be referred to as multi-national 
languages; each of them has more than 300 year's history of national variants development. Russian is also approaching that definition. And there are several reasons for that. Firstly, Russian enjoys the status of the official language in Kazakhstan. Secondly, active language contacts within the country and the extent to which Russian is used in all spheres of public and social life allow us to define it as multi-national.

Geographical, political, socioeconomic and cultural features specific to the Kazakhstan reality have greatly influenced all levels of the language spoken by the ethnic Russian and people of other nationalities who consider Russian their first language, as a result of which, 'a variable layer' has appeared in Russian, while the core has remained the same. Not surprisingly, the lexical layer has been affected most of all: its size has expanded considerably thus causing further changes in other layers, morphological and phonetic in particular. Moreover, we maintain that as a result of language contact not only language is likely to undergo changes, but also the consciousness of speakers of that language.

Thus, national mentality, logic, emotions, means of expressions, moral priorities, etc. of the speaker of Russian surrounded by people who speak a foreign language has undergone and keeps undergoing changes of varying degree.

\section{The specifics of the way Kazakh repatriates master Russian}

The problem of learning Russian by students repatriates (ethnic Kazakhs who study in Kazakhstan universities) is one of the most relevant and insufficiently developed problems. It is very difficult for an individual to adapt to a new socio-cultural setting; one always faces the necessity to realize the uniqueness of this other speaker's world outlook. In addition to that, different alphabets make communication even more difficult: Cyrillic (Kazakhstan and many other countries of CIS), Roman alphabet (Turkey, Western Europe), the ancient Kazakh alphabet "tote zhazu" (China, Iran and Pakistan).

In order to help students, Kazakh repatriates, successfully adapt to a new socio-cultural environment, it is very important to find effective ways to help them successfully learn Russian and to be able to do this. Additionally, it is essential to design a curriculum in such a way so it should be aimed at eliminating intercultural communication problems. Teaching Russian as a foreign language is a multifaceted complex process. One of its important goals is to form students' communication competence through gradual development of their speaking skills, which in turn, is achieved through teaching the language and necessary skills so students will later be able to make use of this knowledge in real life situations when communicating with native speakers.

\section{Methodology}

Different qualitative and quantitative methods are used to achieve the research goals: observation, a method of random selection of regionalisms from the Kazakhstan media texts, systematization, classification, component, semantic and conceptual analysis, a questionnaire and tests.

As part of the study, a sociolinguistic survey was conducted in Akmolinskaya oblast among the speakers of Russian of different ages. The reason why we chose to conduct the survey in the north region of our country is that a great number of non-indigenous 
population lives there. Since the influence of Kazakh on Russian is less traceable there, unlike in the southern regions, the obtained data reflect the real state of Russian lexical system. The aim of the survey was to determine the corpus of the most assimilated and commonly used lexical units of the Kazakh language as well as lexical zones with a high frequency of Kazakh words in them.

2500 informants took part in the survey. The sampling was carried out on the basis of a quota sample, the main parameters being nationality, age, and education.

$82 \%$ of the informants reported Russian as their first language, the remaining $18 \%$ was made up of informants who belonged to other nationalities and also reported Russian as their first language. The national make-up of the latter group is represented by the Polish, German, Belorussian, Ukrainian, Tatar, Korean and others. The Kazakh corpus of lexical units served as the material for questionnaires. These lexical units were grouped into the following semantic spheres: the sphere of social and business communication; social and cultural sphere; the sphere of day-to-day communication; a toponymic sphere; 13 thematic groups in all.

Another aspect of research - the study of the specifics of intercultural communication development and the process of learning Russian by Kazakh repatriates - is based on the experimental data: the results of the survey and tests, associative experiment and interview which were conducted among the first and fourth year returnee-students who specialised in different branches at L.N. Gumilyov Eurasian National University (2017). 100 informants took part in the survey (the first-year students $-60 \%$, the fourth-year students $-40 \%$ ), among them there were students who originally came from China (59\%), Mongolia (23\%), Uzbekistan (18\%).

The research findings concern the specific features of the acquisition of linguistic and cultural knowledge by the students-repatriates as well as the factors that bear on the effectiveness of the acquisition process of such knowledge: the informants' attitude towards Russian, reasons underlying motivation for learning the language, the degree of willingness on the part of the informants to engage in conversation with speakers of Russian.

\section{Results and Discussion}

In this part we dwell on the results of the study. First, we examined Russian as it is used by the ethnic Russian.

\section{Russian as the mother tongue (the use of Russian by the ethnic Russians)}

Language features of this group are associated primarily with lexical borrowing (nonequivalent and equivalent). The practice of using lexical units of the Kazakh language in Russian speech can be called a typical modern phenomenon, as the reality surrounding the speaker requires the use of adequate means of expression. Due to the regularity and frequency of usage, the borrowed units have lost their "alien" nature and are now perceived as natural components of the lexical system of the native language. For instance, sociopolitical vocabulary (akimat, maslikhat, Mazhilis, tenge oralman, zhuz, et al.), sociocultural vocabulary (aitys, aytysker, akyn, kui, kuishi, dombra, shashu, bata, ait, Nauryz, sadaka, suyunshi, oraza et al.), the units belonging to the sphere of everyday communication 
related to the gastronomic discourse (ayran, besbarmak, baursak, kumys, shubat, shuzhyk, kazi, kurt, irimshik, shelpek, sogym et al.), names of people (aksakal, apai, yeah, kudalar, ata, azhe, batyr, dzhigit, ainalayyn et al.), names of buildings, businesses (kumyskhana, yurt, shaykhana, damkhana, duken et al.) and household appliances (korpe tekemets, shanyrak, tabak, kese, kazan, piala, koshma, dastarkhan et al.). This is the body of words related to the realities of life which a speaker faces constantly. These units are effortlessly reproduced in the speech of Russian speakers and are perceived as native units of the language.

The ability to communicate is a global communicative competence, generic concept. Y.E. Prokhorov said that communicative competence "as a generic term includes three specific concepts: existential competence, textual competence and discursive competence. All other competences, although fully entitled to exist, we believe, are more private elements: speech and language competence, of course, "serve" all three types, because the types can explicate only in their shapes in the learning process and in the implementation process; country-studies - part of the existential competence since the latter is wider; professional and objective - one of the manifestations of the object and discursive depending on the type of communicative space in which they are implemented, etc." [2].

The text information is of greatest interest to us because it contains lexical units of another language (in different volumes). Inclusion of the foreign-language text elements does not necessarily mean that the authors could not find the right words in their native language or foreign words to convey a certain sense - rather it indicates familiarity of the speaker/writer with a different culture and maybe with another language, i.e. indicates the absence of a peculiar threshold, making a different culture and a different language no longer alien. As the researchers note, «when native speakers no longer feel the strangeness of the foreign word, it loses signals and accompanying comments and begins to be used "on a par» with other lexical units of the native language" [3].

\section{Russian as a second language (use of Russian by the ethnic Kazakhs)}

Language features of this group are associated with the introduction of the native language units to Russian speech by natural code-switching and active processes in the area of word formation (new words with a borrowed basis). Lexical units borrowed from the Kazakh language are governed by the laws of the Russian language in the wordformative plan. Derivatives of those units, in the formation of which native Russian and foreign-language morphological derivation are updated, are of particular interest.

The most productive and frequent ones are diminutive suffixes -ushk-, -yushk-: kese (a small cup for tea) - kesyushka, piala (cup for broth and tea) - pialushka; -eshksuffixes, and -ishk- -ashk-: apa (older woman, a grandmother) - apashka, aga (male, aged uncle) - agashka, tate (Aunt) - tateshka, korpe (blanket) - korpeshka and others.; suffix $-\mathrm{k}-$ released in feminine nouns denoting objects from the diminutive value: azhe (grandmother) - azheka (only applies to the older woman, a Kazakh); suffix — sk - in the Russian language is used mainly in the adjective derived from the basics of nouns, both proprietary and common nouns: akimat (authority) - akimatovsky, the Majilis (lower chamber of parliament) - mazhilisovsky et al., "Turan" (firm for the production 
of mineral water) - turanovskaya water; "TASSAY" (company specializing in the production of drinking water) - tassayskaya products; "Rakhat" (confectionery in Almaty) - rakhatovskie candy. Derivatives formed from the names of the parties and organizations: Otan (homeland, homeland) - otanovsky, Nur Otan - Nur Otanovsky, Zhuldiz (star) - zhuldyzovsky, Adilet (Justice) - adiletovsky and others. Formation of compound words by adding the word bases, joining foreign language affixoids is used in adapting Kazakh words in the Russian language: kumysodel - (mare (Kaz.) - a fermented milk drink made from mare's milk + do) - a person who is engaged in manufacturing kumys. The word is created by the model of the word «oiler» («maslodel» in Russian). The same pattern works for other units: Temirbank - (temir (kaz.) - the iron, the name of a famous bank in Kazakhstan); rayakimat, gorakimat, oblakimat - (district, city, region + city administration - the local authority of the management): regional, city, and regional administration respectively.

A limited region, a foreign environment, in our case - Kazakhstan, in which Russian operates and develops, helps to complete the lexical structure through loanwords regionalisms, which are adapted to the language with the help of Russian word-formation processes. These units are widely used in the Russian speech, but a wide and varied range of their use can be observed among Kazakhs who know the mother tongue - the Kazakh language.

\section{Russian as a foreign language (use of Russian by Kazakh immigrants and foreign nationals)}

The problem of intercultural competence formation in the language and socio-cultural adaptation of Kazakh repatriates is of special importance, because they are facing not only the problems of mastering a new language system in the process of learning the Russian language, but also a strange, alien culture, while at the same time experiencing considerable difficulties adapting to the new socio-cultural environment. The returneesstudents have repatriated from Uzbekistan, Mongolia, China, Afghanistan and other countries. The immigrant students, who embark on the study of the Russian language in Kazakhstan, have different levels of proficiency in Russian because some of them have studied Russian before entering university. Kazakh repatriates from Mongolia and China have greater difficulty compared to immigrants from Uzbekistan, as they start learning the Russian language mostly only in university. Survey data suggest that immigrant students know the native Kazakh language (100\%), the languages of the countries where they came from (Chinese - 59\%, Mongolian - 23\%, Uzbek - 18\%) as well as languages such as English (29\%), Russian (8\%), Uyghur (6\%), German (3\%), Dungan (2\%), Kyrgyz $(1 \%)$, Turkish (1\%). Russian is among the languages which are less spoken in everyday communication. The results of the survey, testing, interviewing, and association experiment revealed the features of intercultural competence formation of students-returnees. It was found that the motives for studying Russian are different: 1) some study Russian with the cognitive and professional purpose in mind; 2) others study Russian in order to facilitate the adaptation process in the modern Kazakh society; 3) still others reported that they were learning Russian because they were expected to since it was part of their curriculum.

Low activity in forming relationships with representatives of Russian nationality is related to unfamiliarity with the language and a negative attitude of some foreign students. 
The process of adaptation and integration of immigrant students into modern Kazakhstan society is complex and depends on many factors. One of them is the communication experience with representatives of other cultures. The degree of communication with students of immigrant Russian-speaking citizens reflect the following results showing their dynamics: the first-year students $(73,3 \%)$ have no friends of Russian nationality, while the majority of undergraduates $(65 \%)$ have reported to have Russian friends. Mechanisms of learning and knowledge externalization of immigrant students in the study of the Russian language, as well as the specificity of formation of intercultural competence depend on intralinguistic and extralinguistic factors [4].

The study results reveal the specifics of cultural and linguistic interaction and mechanisms of formation of intercultural competence of different ethnic group members living in a multiethnic society and thus engaged in an ongoing intercultural dialogue.

\section{Conclusion}

A feature of the multinational Russian language in relation to other multinational languages is that it is manifested not only in the language of other ethnic groups using it as a mother tongue in intra or inter-ethnic dialogue, but also in the language of the ethnic Russian living in multi-ethnic states, particularly in Kazakhstan.

Because the Russian language experiences considerable influence from Kazakh, the lexical system of the multinational Russian language has acquired a number of specific features which has made it possible for a new national variant to come about outside the main area of its existence [5].

Special forms of language interaction, leading to the development of special sociocultural experience of the individual, the mastery of their respective models of speech behavior, the adequacy of a given society norms of communication are produced with the wide distribution and use of the Russian language by representatives of Russian nationality, for whom it is native, and people of other nationalities, especially Kazakh, including Kazakh immigrants in modern Kazakhstan reality.

Monitoring of cultural and linguistic interaction which allows to reveal the mechanisms of formation of a tolerant personality in the context of multilingual educational space and multi-ethnic society of modern Kazakhstan, is one of the research areas of scientific laboratory "Applied Linguistics and Intercultural Communication" at the Department of Theoretical and Applied Linguistics at L.N. Gumilyov ENU. Attempts to identify the mechanisms and the specific formation of intercultural competence of representatives of different ethnic groups living in a multiethnic society and engaging in a constant intercultural dialogue have been made in the research conducted under the guidance and direct participation of the authors.

\section{References}

1. Dave, B. \& Sinnott, P. 2002. Demographic and Language Politics in the 1999 Kazakhstan Census. Watson Institute, Brown University, the National Council for Eurasian and East European Research. Pp. 5-8. Print.

2. Prokhorov, Yu.E. 2005. "Russkii yazyk v novom kommunikativnom prostranstve XXI veka". In Sostoyanie russkogo yazyka i prepodavanie na russkom yazyke za predelami Rossii. Vozmozhnosti 
ispol'zovaniya mezhdunarodnogo opyta: Collection of abstracts of Research-Practical Conference. Kishinev: VALINEX. Print. (In Russ.)

3. Mirzoyan, S.V. 2003. "Adaptacija zaimstvovannyh slov". History of linguistics, literature study and journalism as the basis of modern philological knowledge. Volume 2. History. Culture. Language: 108. (In Russ.)

4. Agmanova, A.E. 2018. "Specifika jazykovoj podgotovki studentov kazahov-repatriantov". In Russkij jazyk i literatura $v$ tjurkojazychnom mire: sovremennye koncepcii i tehnologii: Collection of abstracts of Research-Practical Conference (Kazan', November, 29 - December, 1, 2018). In 2 volumes. Edited by d. R.R. Zamaletdinova, T. G. Bochina, Yu. V. Ageeva. Kazan: Kazan University Publishing House, 2018. Vol. 1. Pp. 17-21. Print. (In Russ.).

5. Zhuravleva, E. 2016. “Trends in the Formation of Kazakhstan's Variety of Russian”. In Pluricentric Languages and Non-Dominant Varieties. Worldwide: Volume 1: Pluricentric Languages across Continents Features and Usage. Frankfurt a.M. / Wien u.a., Peter Lang Verlag. Print.

\section{Список литературы}

1. Dave B., Sinnott P. Demographic and Language Politics in the 1999 Kazakhstan Census. Watson Institute, Brown University, the National Council for Eurasian and East European Research, 2002. Pp. 5-8.

2. Прохоров Ю.Е. Русский язык в новом коммуникативном пространстве XXI века // Состояние русского языка и преподавание на русском языке за пределами России. Возможности использования международного опыта: материалы научно-практической конференции. КИшинев: ВАЛИНЕКС, 2005.

3. Мирзоян С.В. Адаптация заимствованных слов // История языкознания, литературоведения и публицистики как основа современных филологических знаний. Т. 2. История. Культура. Язык. М., 2003.

4. Агманова А.Е. Специфика языковой подготовки студентов казахов-репатриантов // Русский язык и литература в тюркоязычном мире: современные концепции и технологии: материалы научно-практической конференции (Казань, 29 ноября - 1 декабря, 2018). В 2 т. Ред. Р.Р. Замалетдинова, Т.Г. Бочина, Ю.В. Агеева. Казань: Издательство Казанского ун-та, 2018. Т. 1. С. 17-21.

5. Zhuravleva E. Trends in the Formation of Kazakhstan's Variety of Russian // Pluricentric Languages and Non-Dominant Varieties. Worldwide: Volume 1: Pluricentric Languages across Continents Features and Usage. Frankfurt a.M. / Wien u.a., Peter Lang Verlag, 2016.

\section{Bio Note:}

Yevgeniya A. Zhuravleva is a Doctor of Philology, Professor, Head of Theoretical and Applied Linguistics, The L.N. Gumilyov Eurasian National University. E-mail: zhuravleva_ea@enu.kz

Atirkul E. Agmanova is a Doctor of Philology, Professor of the Higher School of Humanities of Pavlodar Pedagogical University. E-mail: agmanova@mail.ru

\section{Сведения об авторах:}

Журавлёва Евгения Александровна - доктор филологических наук, профессор, зав. кафедрой теоретической и прикладной лингвистики филологического факультета Евразийского национального университета им. Л.Н. Гумилёва. E-mail: zhuravleva_ea@enu.kz

Агманова Атиркуль Егембердиевна - доктор филологических наук, профессор, профессор Высшей школы гуманитарных наук Павлодарского педагогического университета. E-mail: agmanova@mail.ru 